\title{
STUDIES ON COPPER METABOLISM. VI. BLOOD COPPER IN NORMAL HUMAN SUBJECTS ${ }^{1}$
}

\author{
By M. E. LAHEY,² C. J. GUBLER, G. E. CARTWRIGHT, AND M. M. WINTROBE \\ (From the Departments of Medicine and Pediatrics, University of Utah College of Medicine, \\ Salt Lake City, Utah)
}

(Submitted for publication September 30, 1952; accepted December 31, 1952)

Although copper was recognized as a normal constituent of blood in about 1870 (1), relatively few studies have been made on the metabolism of this element in human subjects. The value of the work of earlier investigators is limited because the methods used were inadequate. Within the past 10 years, however, several workers, by the use of more reliable methods, have measured the copper content of whole blood and plasma in the normal human subject (2-11). Cartwright (12) has recently reviewed this literature in detail.

A simple and accurate method for the determination of copper in whole blood, plasma and red blood cells has been developed in our laboratory recently (13). In view of the inadequate available data concerning certain aspects of copper metabolism in the human subject to which reference will be made later, and the disagreement regarding other aspects, it was considered worthwhile to undertake a comprehensive investigation of blood copper values in the normal human subject under various physiological conditions. The results of this study are presented herewith.

1 This investigation was supported by a research grant from the National Institutes of Health, Public Health Service.

2 National Research Council Fellow in the Medical Sciences, 1949-1951.

\section{METHODS AND MATERIALS}

Determinations of whole blood, plasma and red blood cell (RBC) copper were made by the method of Gubler and his associates (13). In many, but not all instances, duplicate determinations were done; in such instances the mean value was used.

The subjects studied were not given physical examinations but were apparently healthy individuals, ranging in age from 20 to 40 years, who were actively engaged in their work as medical students, doctors, nurses or laboratory technicians.

\section{RESULTS}

A. Normal values. The values for whole blood and plasma copper in 63 subjects and for RBC copper in 31 subjects are shown in Table I. Blood samples were obtained in the morning but the subjects were not necessarily fasting nor otherwise under basal conditions.

Values for whole blood copper (W.B.Cu) ranged from 70 to $117 \mu \mathrm{g}$. per $100 \mathrm{ml}$. blood in the male, and from 69 to $117 \mu \mathrm{g}$. per $100 \mathrm{ml}$. in the female. Only the one value of $69 \mu \mathrm{g}$. per $100 \mathrm{ml}$. was greater than two standard deviations from the mean.

Values for plasma copper ( $\mathrm{Pl} . \mathrm{Cu}$ ) ranged from 68 to $134 \mu \mathrm{g}$. per $100 \mathrm{ml}$. plasma in the male, and from 84 to $143 \mu \mathrm{g}$. per $100 \mathrm{ml}$. in the female. The value of $68 \mu \mathrm{g}$. per $100 \mathrm{ml}$. found in two male sub-

TABLE I

Blood copper values in normal human subjects

\begin{tabular}{|c|c|c|c|c|c|c|}
\hline \multirow[b]{2}{*}{ Sex } & \multicolumn{2}{|c|}{ Whole blood copper } & \multicolumn{2}{|c|}{ Plasma copper } & \multicolumn{2}{|c|}{ RBC copper } \\
\hline & $\begin{array}{c}\text { No. } \\
\text { subjects }\end{array}$ & $\mu \mathrm{g} . / 100 \mathrm{ml} .^{*}$ & $\begin{array}{c}\text { No. } \\
\text { subjects }\end{array}$ & $\mu \mathrm{g} . / 100 \mathrm{ml} . *$ & $\begin{array}{c}\text { No. } \\
\text { subjects }\end{array}$ & $\mu \mathrm{g} . / 100 \mathrm{ml} . *$ \\
\hline Male & 40 & $\begin{array}{r}96 \\
+13\end{array}$ & 40 & $\begin{array}{r}105 \\
\pm 16\end{array}$ & 19 & $\begin{array}{r}110 \\
\pm 16\end{array}$ \\
\hline Female & 23 & $\begin{array}{r}100 \\
\pm 11\end{array}$ & 23 & $\begin{array}{r}116 \\
\pm 16\end{array}$ & 12 & $\begin{array}{r}122 \\
\pm 29\end{array}$ \\
\hline Total & 63 & $\begin{array}{r}98 \\
\pm 13\end{array}$ & 63 & $\begin{array}{r}109 \\
\pm 17\end{array}$ & 31 & $\begin{array}{r}115 \\
\pm 22\end{array}$ \\
\hline
\end{tabular}

* Figures refer to mean \pm standard deviation. 
TABLE II

Diurnal variation in plasma copper and red blood cell copper in male subjects

\begin{tabular}{|c|c|c|c|c|c|c|c|c|c|c|c|c|}
\hline \multirow[b]{2}{*}{ Subject } & \multicolumn{6}{|c|}{ Plasma copper, $\mu \mathrm{g} . / 100 \mathrm{ml}$. } & \multicolumn{6}{|c|}{ Red blood cell copper, $\mu \mathrm{g} . / 100 \mathrm{ml}$. } \\
\hline & $\begin{array}{c}8 \\
\text { a.m. }\end{array}$ & $\begin{array}{c}12 \\
\text { noon }\end{array}$ & $\begin{array}{c}3 \\
\text { p.m. }\end{array}$ & $\begin{array}{c}6 \\
\text { p.m. }\end{array}$ & $\stackrel{9}{\text { p.m. }}$ & $\begin{array}{l}12 \\
\text { midnight }\end{array}$ & $\begin{array}{c}8 \\
\text { a.m. }\end{array}$ & $\begin{array}{c}12 \\
\text { noon }\end{array}$ & $\begin{array}{c}3 \\
\text { p.m. }\end{array}$ & $\begin{array}{c}6 \\
\text { p.m. }\end{array}$ & $\begin{array}{c}9 \\
\text { p.m. }\end{array}$ & $\begin{array}{l}12 \\
\text { midnight }\end{array}$ \\
\hline $\begin{array}{r}1 \\
2 \\
3 \\
4 \\
5 \\
6 \\
7 \\
8 \\
9 \\
10 \\
11\end{array}$ & $\begin{array}{r}116 \\
134 \\
113 \\
89 \\
95 \\
113 \\
80 \\
68 \\
111 \\
81 \\
105\end{array}$ & $\begin{array}{r}122 \\
140 \\
110 \\
80 \\
86 \\
130 \\
93 \\
92 \\
107 \\
87 \\
98\end{array}$ & $\begin{array}{r}140 \\
140 \\
122 \\
83 \\
101 \\
125 \\
74 \\
77 \\
122 \\
78 \\
95\end{array}$ & $\begin{array}{r}137 \\
163 \\
128 \\
86 \\
101 \\
131 \\
84 \\
89 \\
117 \\
81 \\
105\end{array}$ & $\begin{array}{r}128 \\
131 \\
122 \\
77 \\
101 \\
125 \\
86 \\
89 \\
111 \\
77 \\
105\end{array}$ & $\begin{array}{r}128 \\
143 \\
116 \\
86 \\
92 \\
119 \\
83 \\
89 \\
108 \\
77 \\
105\end{array}$ & $\begin{array}{r}100 \\
99 \\
114 \\
109 \\
108 \\
88 \\
102 \\
102\end{array}$ & $\begin{array}{r}110 \\
94 \\
95 \\
130 \\
84 \\
85 \\
91 \\
102\end{array}$ & $\begin{array}{r}\overline{138} \\
119 \\
101 \\
79 \\
104 \\
98 \\
102\end{array}$ & $\begin{array}{r}138 \\
96 \\
175 \\
110 \\
79 \\
94 \\
126 \\
110\end{array}$ & $\begin{array}{r}127 \\
115 \\
100 \\
151 \\
82 \\
102 \\
120 \\
105\end{array}$ & $\begin{array}{r}92 \\
95 \\
82 \\
118 \\
99 \\
104 \\
142 \\
157\end{array}$ \\
\hline $\begin{array}{l}\text { Mean } \\
\pm \text { S.E. }\end{array}$ & $\begin{array}{r}101 \\
\pm 5.90\end{array}$ & $\begin{array}{r}104 \\
\pm 6.08\end{array}$ & $\begin{array}{r}105 \\
\pm 7.68\end{array}$ & $\begin{array}{r}111 \\
\pm 7.95\end{array}$ & $\begin{array}{r}105 \\
\pm 6.12\end{array}$ & $\begin{array}{r}104 \\
\pm 6.64\end{array}$ & $\begin{array}{r}103 \\
\pm 2.78\end{array}$ & $\begin{array}{r}99 \\
\pm 5.37\end{array}$ & $\begin{array}{r}106 \\
\pm 6.50\end{array}$ & $\begin{array}{r}116 \\
\pm 10.68\end{array}$ & $\begin{array}{r}113 \\
\pm 7.32\end{array}$ & $\begin{array}{r}111 \\
\pm 9.23\end{array}$ \\
\hline
\end{tabular}

jects, was more than two standard deviations from the mean.

Values for RBC copper ranged from 84 to 141 $\mu \mathrm{g}$. per $100 \mathrm{ml}$. red blood cells in the male, and from 84 to $159 \mu \mathrm{g}$. per $100 \mathrm{ml}$. in the female subjects. All values were within the range of the mean \pm two standard deviations.

The mean plasma copper for females was significantly higher than that for males $(t=2.67, p$ near 1 per cent). There was no significant differ- the 19 males and in 11 of the 12 female subjects, calculated RBC copper was lower than the determined $R B C$ copper, in several instances by as much as 35 to 55 per cent.

The ratio of determined red cell copper to plasma copper for the male subjects was 1.04 and for the female subjects 1.05 .

The amount of copper in the average red corpuscles (mean corpuscular copper) may be calculated by means of the formula:

$$
\text { Mean corpuscular copper }=\frac{\operatorname{RBC~Cu}(\mu \mathrm{g} \cdot \operatorname{per} 100 \mathrm{ml} .) \times \frac{\operatorname{VPRC}(\mathrm{ml} \text {. per } 100 \mathrm{ml} .)}{100}}{\mathrm{RBC}(\text { millions }) \times 10^{6} \times 10^{5}} .
$$

ence in the whole blood and RBC copper values in the two sexes.

$\mathrm{RBC}$ copper can be calculated by substituting in an appropriate formula ${ }^{3}$ the determined values for whole blood and plasma copper. If this is done for the 19 male and 12 female subjects on whom $\mathrm{RBC}$ copper was actually determined, values of 91 and $90 \mu \mathrm{g}$. per $100 \mathrm{ml}$., respectively, are obtained. (The mean VPRC-volume packed red cells-for the men was $50 \mathrm{ml}$. per $100 \mathrm{ml}$. and for the woman $45 \mathrm{ml}$. per $100 \mathrm{ml}$.) The mean calculated values were thus somewhat lower than the mean determined values for RBC copper. Examination of the individual data reveals that in 15 of

Red Cell Copper

$$
=\frac{\text { W. B. Cu }(100)-\text { Pl. Cu (100 - VPRC) }}{\text { VPRC }} \text {. }
$$

W. B. Cu refers to whole blood copper expressed in $\mu \mathrm{g}$. per $100 \mathrm{ml}$. blood; P1. Cu refers to plasma copper expressed in $\mu \mathrm{g}$. per $100 \mathrm{ml}$. plasma ; VPRC refers to volume of packed red cells in ml. per $100 \mathrm{ml}$. blood.
For the 31 subjects in whom RBC copper was determined, the mean red cell count was $5.51 \times$ $10^{8}$ per mm..$^{3}$ and the mean VPRC was $48 \mathrm{ml}$. per $100 \mathrm{ml}$. According to the above formula, a value of $100 \mu \mu \mu \mathrm{g}$. for the mean corpuscular copper is obtained.

B. Diurnal variation. Plasma copper determinations were made on 11 healthy male subjects at the time intervals shown in Table II, beginning at 8 a.m. and ending at midnight. In addition, on eight of these 11 subjects RBC copper determinations were made at the same time intervals. The initial blood samples were drawn with the subjects fasting but not otherwise under basal conditions. Throughout the day each subject engaged in his usual activity.

The mean value for plasma copper at 8 a.m. was $101 \mu \mathrm{g}$. per $100 \mathrm{ml}$. plasma and at 6 p.m. was 111 $\mu \mathrm{g}$. per $100 \mathrm{ml}$. This general pattern of a rise in plasma copper in the afternoon with a fall in the 
evening occurred in nine of the 11 subjects studied. The peak did not appear uniformly at 6 p.m. but in two subjects occurred at noon, and in two others at 3 p.m. While the majority of individuals exhibited an increase of 6 to $15 \mu \mathrm{g}$. during the afternoon, one subject's plasma copper rose from $134 \mu \mathrm{g}$. per $100 \mathrm{ml}$. at 8 a.m. to $163 \mu \mathrm{g}$. per $100 \mathrm{ml}$. at 6 p.m., an increase of $29 \mu \mathrm{g}$. or 22 per cent. In one individual there was essentially no fluctuation during the day; in another an actual decrease in plasma copper occurred, from $89 \mu \mathrm{g}$. per $100 \mathrm{ml}$. at $8 \mathrm{a} . \mathrm{m}$. to $77 \mu \mathrm{g}$. per $100 \mathrm{ml}$. at 9 p.m. Statistical analysis of the data reveals that the differences between the 8 a.m. values and the values at the time of maximal change, would occur by chance only two times out of 100 ( $p=2$ per cent).

The mean value for $\mathrm{RBC}$ copper at 8 a.m. was $103 \mu \mathrm{g}$. per $100 \mathrm{ml}$. red blood cells and at 6 p.m. was $116 \mu \mathrm{g}$. per $100 \mathrm{ml}$. While there was a general tendency for $\mathrm{RBC}$ copper to be elevated in the afternoon and evening in seven of the eight subjects studied, individual variations in actual $\mu \mathrm{g}$. per $100 \mathrm{ml}$. were greater than for plasma copper. The highest value for $\mathrm{RBC}$ copper did not appear uniformly at 6 p.m. but occurred at 3 p.m. in two, at 9 p.m. in one, and at midnight in two. In one subject, $\mathrm{RBC}$, copper actually decreased from $108 \mu \mathrm{g}$. per $100 \mathrm{ml}$. at 8 a.m. to $79 \mu \mathrm{g}$. per $100 \mathrm{ml}$. at 3 p.m. and then rose to $99 \mu \mathrm{g}$. per $100 \mathrm{ml}$. at midnight. The differences between the 8 a.m. values and the values at the time of maximal change would occur by chance only once or twice out of 100 times ( $\mathrm{p}$ between 1 and 2 per cent).

C. Day to day and week to week variation. Blood was obtained for plasma copper determinations from each of eight healthy male subjects on

TABLE III

Day to day variation in plasma copper in eight healthy male subjects

\begin{tabular}{|c|c|c|c|c|c|}
\hline Subject & 1 & 2 & $\begin{array}{c}\operatorname{ma}^{2} / 100 \mathrm{n} \\
\mathrm{Day} \\
3\end{array}$ & 4 & 5 \\
\hline $\begin{array}{l}1 \\
2 \\
3 \\
4 \\
5 \\
6 \\
7 \\
8\end{array}$ & $\begin{array}{r}77 \\
95 \\
90 \\
110 \\
96 \\
107 \\
81 \\
98\end{array}$ & $\begin{array}{r}80 \\
80 \\
96 \\
107 \\
111 \\
78 \\
110\end{array}$ & $\begin{array}{r}84 \\
96 \\
90 \\
99 \\
110 \\
110 \\
80 \\
108\end{array}$ & $\begin{array}{r}98 \\
108 \\
99 \\
110 \\
128 \\
- \\
-\end{array}$ & $\begin{array}{r}92 \\
104 \\
95 \\
\\
98 \\
81 \\
103\end{array}$ \\
\hline
\end{tabular}

successive days, with the exceptions noted in Table III. The individuals fasted over night and samples were obtained in the morning before breakfast. An analysis of variance shows that the day to day variation is not significant ( $p$ greater than 20 per cent).

In addition, plasma copper determinations were made on subjects 3 and 7 and one other male subject at weekly intervals for three weeks. In the first, second and third weeks, values for subject 3 were 83,96 , and 75 , respectively, for subject 7 , they were 96,74 , and 81 , and for the third subject they were 95,98 , and $98 \mu \mathrm{g}$. per $100 \mathrm{ml}$. plasma, respectively. The sampling was too small to lend itself to statistical analysis, but it is apparent that the changes were small.

TABLE IV

The effect of the ingestion of food on the plasma copper level

\begin{tabular}{lccccc}
\hline \hline & \multicolumn{5}{c}{$\begin{array}{c}\text { Plasma copper } \\
\text { Mg./100 ml. } \\
\text { Subject }\end{array}$} \\
$\begin{array}{l}\text { Relation } \\
\text { to meal }\end{array}$ & 1 & 2 & 3 & 4 & 5 \\
\hline Before & 105 & 96 & 92 & 95 & 105 \\
After & 102 & 98 & 99 & 105 & 106
\end{tabular}

D. Variation with meals. For the purpose of determining the effect of food ingestion on the plasma copper level, blood samples were examined before and two and one-half hours after the noon meal in five healthy male subjects. The results are presented in Table IV and show that only a very slight and insignificant rise took place in the plasma copper levels of four of the five individuals studied. The average increase in these five subjects was less than $4 \mu \mathrm{g}$. per $100 \mathrm{ml}$.

E. Variation with menstruation. Five healthy female subjects, ages 27 to 36 years, were studied to determine the variation in blood copper during the menstrual cycle. Because of the difficulties entailed, no attempt was made to obtain venous blood samples immediately before or after the time of actual menstrual flow, nor at the mid-point in the menstrual cycle. Instead, blood samples were obtained from each of the five subjects on the same day of the week for 20 weeks. Thus, in each subject determinations were made before and after each of four periods of menstrual flow. A calendar of the first day of menstrual flow was kept for each subject. The plasma copper determination made on the day nearest to the day of actual 
TABLE V

Variations in plasma copper with menstruation

\begin{tabular}{|c|c|c|c|c|c|c|c|}
\hline \multirow[b]{2}{*}{ Subject } & \multicolumn{3}{|c|}{$\begin{array}{l}\text { Weeks before } \\
\text { menstruation }\end{array}$} & \multirow{2}{*}{$\begin{array}{l}\text { First } \\
\text { day of } \\
\text { menses }\end{array}$} & \multicolumn{3}{|c|}{$\begin{array}{c}\text { Weeks after } \\
\text { menstruation }\end{array}$} \\
\hline & 3 & 2 & 1 & & 1 & 2 & 3 \\
\hline Mean & $\begin{array}{l}116 \\
112\end{array}$ & $\begin{array}{r}113 \\
95 \\
\\
124 \\
111\end{array}$ & $\begin{array}{r}107 \\
102 \\
112 \\
87 \\
102\end{array}$ & $\begin{array}{l}108 \\
116 \\
115 \\
112 \\
113\end{array}$ & $\begin{array}{r}95 \\
122 \\
116 \\
105 \\
110\end{array}$ & $\begin{array}{l}102 \\
124 \\
124 \\
110 \\
115\end{array}$ & $\begin{array}{l}87 \\
87\end{array}$ \\
\hline 2 & 128 & $\begin{array}{l}122 \\
110\end{array}$ & $\begin{array}{l}107 \\
104\end{array}$ & $\begin{array}{r}110 \\
107 \\
96\end{array}$ & 128 & 110 & 104 \\
\hline Mean & $\begin{array}{l}102 \\
115\end{array}$ & $\begin{array}{l}112 \\
115\end{array}$ & $\begin{array}{l}124 \\
112\end{array}$ & $\begin{array}{r}89 \\
101\end{array}$ & $\begin{array}{l}102 \\
111\end{array}$ & $\begin{array}{l}112 \\
111\end{array}$ & $\begin{array}{l}101 \\
110\end{array}$ \\
\hline Mean & $\begin{array}{l}101 \\
124 \\
113\end{array}$ & $\begin{array}{r}105 \\
98 \\
96 \\
83 \\
96\end{array}$ & $\begin{array}{r}92 \\
92 \\
104 \\
96 \\
96\end{array}$ & $\begin{array}{r}97 \\
107 \\
114 \\
105 \\
106\end{array}$ & $\begin{array}{l}101 \\
107 \\
124 \\
104 \\
109\end{array}$ & $\begin{array}{l}98 \\
83 \\
91\end{array}$ & $\begin{array}{l}92 \\
96 \\
94\end{array}$ \\
\hline 4 & $\begin{array}{r}116 \\
98\end{array}$ & $\begin{array}{l}113 \\
101\end{array}$ & $\begin{array}{r}107 \\
98\end{array}$ & $\begin{array}{l}104 \\
116 \\
102\end{array}$ & $\begin{array}{r}98 \\
105\end{array}$ & 101 & 98 \\
\hline Mean & $\begin{array}{l}105 \\
106\end{array}$ & $\begin{array}{l}104 \\
106\end{array}$ & $\begin{array}{l}124 \\
110\end{array}$ & $\begin{array}{r}93 \\
104\end{array}$ & $\begin{array}{l}102 \\
102\end{array}$ & $\begin{array}{r}99 \\
101\end{array}$ & $\begin{array}{l}104 \\
109\end{array}$ \\
\hline 5 & 109 & $\begin{array}{l}119 \\
124 \\
112\end{array}$ & $\begin{array}{l}125 \\
119 \\
124\end{array}$ & $\begin{array}{l}119 \\
136 . \\
131\end{array}$ & $\begin{array}{l}113 \\
133\end{array}$ & $\begin{array}{l}116 \\
109\end{array}$ & $\begin{array}{l}121 \\
112\end{array}$ \\
\hline Mean & 109 & 118 & 123 & 129 & 123 & 113 & 117 \\
\hline
\end{tabular}

Results are expressed in $\mu \mathrm{g}$. per $100 \mathrm{ml}$.

onset of menstrual flow is recorded in Table $\mathrm{V}$ as representing the plasma copper on the first day of the menses. The remaining determinations are given as they fell at weekly intervals before or after the "first day" of menses. A total of 103 plasma copper determinations were made.

From the values recorded, it would seem that plasma copper is quite stable in the menstruating female subject, with no tendency to change consistently in either direction in the weeks prior to or after the onset of the menses. In none of the individuals were values found outside the previously defined normal range.

RBC copper determinations were made concurrently with those for plasma copper, but, for the sake of brevity, are not presented. These values were also found to be relatively constant. In a single individual, while the RBC levels fluctuated to a greater extent than did the plasma values, there was no tendency toward a consistent change in either direction in the weeks before or after the menses.

\section{DISCUSSION}

The values, $98 \pm 13 \mu \mathrm{g}$. per $100 \mathrm{ml}$. for whole blood copper and $109 \pm 17 \mu \mathrm{g}$. per $100 \mathrm{ml}$. for plasma copper in the 63 normal subjects studied, are in excellent agreement with the values published by other investigators. Thus in 91 subjects of both sexes studied by five investigators $(2,7$, 9-11), the mean value for whole blood copper varied only between 91 and $110 \mu \mathrm{g}$. per $100 \mathrm{ml}$. blood with individual values ranging from 73 to $147 \mu$ g. per $100 \mathrm{ml}$. In 504 subjects studied by nine investigators $(2-8,10,11)$, the mean value for plasma copper varied between 84 and $126 \mu \mathrm{g}$. per $100 \mathrm{ml}$., with individual values ranging from 64 to $165 \mu \mathrm{g}$. per $100 \mathrm{ml}$.

No difference in whole blood copper between the sexes has been reported, but several investigators have found the plasma copper to be significantly higher in women (2-5). Only Heilmeyer (7) who examined the blood of 30 males and 30 females found no difference between the plasma copper values in the two sexes. Although in a preliminary study from this laboratory (12) no significant difference in plasma copper was found between males and females, the data for a greater number of individuals, presented here, indicate that plasma copper is significantly higher in the female.

Heretofore, with but one exception (10) the copper content of the red blood cell has been calculated by substituting in an appropriate formula the values for whole blood and plasma copper in $\mu \mathrm{g}$. per $100 \mathrm{ml}$. $(2,7,11)$. The reported values vary rather widely and there is disagreement regarding the ratio of plasma copper to red blood cell copper. Furthermore, our own direct determinations of red cell copper yielded higher values than those calculated from whole blood and plasma copper. The lack of agreement between the determined and the calculated red cell copper concentrations has been shown (13) to be due to the summation of the errors involved in the several measurements required for the calculation of the red cell copper concentration. The largest contribution to this error comes from the determination of the whole blood copper. By the method used, this is more variable than the plasma copper determination and the values obtained are lower by an average of 7 per cent than those determined following wet ash- 
ing of whole blood. Although the direct determination of red cell copper is somewhat less accurate than the measurement of plasma copper, it is significantly more accurate than the determination of whole blood copper and is greatly to be preferred over the calculation of red cell copper from the whole blood and plasma values. This is particularly true in studies of anemic states.

The criticism may be offered that in the method used herein no attempt was made to separate leukocytes and platelets from red blood cells prior to the determination of copper in the washed red cells and that this might result in an abnormally high value for $R B C$ copper. In answer, it has been pointed out (13) that, while leukocytes contain about as much copper as erythrocytes, they make up such a small fraction of the total cell volume that their contribution to the cell copper is negligible and can be ignored.

On the basis of actually determined RBC copper, the ratio of cell copper to plasma copper becomes 1.04 in males and 1.05 in females, rather than the lower figures we reported earlier (12) or those which can be derived from the data of Holmberg (11) and Munch-Petersen (2), all of which are based on calculated values for cell copper. Thus it appears that the copper content of the red cells when expressed on a weight-volume basis, is essentially equal to that of plasma. Such a conclusion is in agreement with that of Heilmeyer, Keiderling and Stüwe (7). However, if the data are expressed in terms of the water content, the red cell copper concentration is approximately 185 $\mu \mathrm{g}$. per $100 \mathrm{ml}$. of water and the plasma copper concentration is approximately $117 \mu \mathrm{g}$. per $100 \mathrm{ml}$. of water.

Recalculations, based on actual measurements of cell copper, yield the value of $100 \mu \mu \mu \mathrm{g}$. for the amount of copper in the average red corpuscle ("mean corpuscular copper"), rather than the lower figure cited in an earlier report (12).

The data available in the literature indicate that plasma copper values vary relatively little from individual to individual. Variations from day to day in the same individual, however, have not been studied adequately. Heilmeyer, Keiderling and Stüwe (7) found no diurnal variations in plasma copper, while Munch-Petersen (14) and Nielsen (4) found the values to be lowest in the morning, rising somewhat during the forenoon or evening.
Munch-Petersen (14) also noted a tendency for copper concentrations to decrease during periods of sleep in the day or the night and assumed that plasma copper, like plasma iron, is regulated by the same factors which regulate sleep. In the present study copper determinations were made only between 8 a.m. and midnight and not during sleep. The lowest values were found in the morning, rose to a peak at 6 p.m. and then declined. In general, however, the diurnal variation found in this study as well as in those of Nielsen and MunchPetersen was quite small in comparison with that occurring in plasma iron levels in man (15). Thus, of the 63 determinations of plasma copper done during the course of studying diurnal variation, only five were outside the limits previously established for plasma copper in the normal male.

A diurnal variation in $\mathrm{RBC}$ copper has not been reported previously. The results of the present study indicate that, like plasma copper, values for $\mathrm{RBC}$ are lowest in the morning and rise somewhat in the afternoon and evening. The variation is relatively small. Of the 47 determinations done during the course of the study, only three were outside the limits established for RBC copper in the normal male.

Robinson (8) and Heilmeyer, Keiderling and Stüwe (7) found very little change in plasma copper from week to week. Nielsen (4), on the other hand, in studies on five normal women at intervals of two to three days, found considerable variation from time to time, though not outside his normal limits for individual determinations. No cyclic pattern of variation has been observed. In the present study, the day to day and week to week variation in plasma copper was insignificant, thus confirming the reports of others.

It was found that variations with meals are negligible, as Heilmeyer, Keiderling, and Stüwe (7) had previously reported. Neither physical exertion nor meals have any effect on plasma copper, according to Heilmeyer, Keiderling and Stüwe (7).

There has been disagreement regarding variations in plasma copper during the menstrual cycle. Nielsen (4), Locke, Main and Rosbash (16), Heilmeyer, Keiderling, and Stüwe (7), and Sachs, Levine and Griffith (17) found no correlation, while Sarata (10) noted an elevation of both plasma and red blood cell copper immediately be- 
fore the onset of menstrual flow. It seems clear that the amount of copper lost through the normal menstrual flow is small (18). The results of the present study indicate that, while a change of as much as 33 per cent may occur in the plasma copper level in a single individual during the menstrual cycle, the variation is not outside the normal limits established for the female. Values for RBC copper were also found to be relatively constant during the mentrual cycle.

\section{SUM MARY}

By the use of a method recently developed in this laboratory, values have been found for whole blood copper of $96 \pm 13 \mu \mathrm{g}$. and $100 \pm 11 \mu \mathrm{g}$. per $100 \mathrm{ml}$. blood in the male and female, respectively, and for plasma copper of $105 \pm 16 \mu \mathrm{g}$. and $116 \pm 16$ $\mu \mathrm{g}$. per $100 \mathrm{ml}$. plasma in the male and female, respectively. These values are in excellent agreement with those given by other investigators. Published observations that plasma copper is significantly higher in females than in males, have been confirmed. The copper content of red blood cells has been determined directly and values of $110 \pm 16 \mu \mathrm{g}$. in males and $122 \pm 29 \mu \mathrm{g}$. per 100 $\mathrm{ml}$. of red blood cells in females are reported. It is pointed out that the direct measurement of red cell copper is more accurate than the calculation of $\mathrm{RBC}$ copper from whole blood and plasma copper values.

The amount of copper in the red cells, when expressed on a weight-volume basis, has been found to be essentially equal to that in the plasma. The calculated amount of copper in the average red corpuscle (mean corpuscular copper): is approximately $100 \mu \mu \mu \mathrm{g}$.

A very small diurnal variation in plasma copper has been observed. Compared with that which takes place in plasma iron levels in man, however, the variation is small. A slight diurnal variation in $\mathrm{RBC}$ copper has been demonstrated.

Variations from day to day, from week to week, with meals and with menstruation have been found to be of insignificant degree.

\section{ACKNOWLEDGMENTS}

We are indebted to Miss Helen Ashenbrucker, Mrs. Jean Van Dilla, Miss Doris Kurth, Miss Jean Robinson, and Miss Betty Tatting for technical assistance, and to the numerous and cooperative hospital employees who acted as subjects.

\section{REFERENCES}

1. Porter, J. A., Principles of Chemistry. A. S. Barnes \& Co., New York, 1868, 20th ed.

2. Munch-Petersen, S., On the amount of copper in human erythrocytes at different serum copper levels. Scandinav. J. Clin. \& Lab. Invest., 1950, $2,53$.

3. Munch-Petersen, S., On serum copper in angina simplex and in infectious mononucleosis. Acta med. Scandinav., 1948, 131, 588.

4. Nielsen, A. L., On serum copper. III. Normal values. Acta med. Scandinav., 1944, 118, 87.

5. Cartwright, G. E., Huguley, C. M., Jr., Ashenbrucker, H., Fay, J., and Wintrobe, M. M., Studies on free erythrocyte protoporphyrin, plasma iron and plasma copper in normal and anemic subjects. Blood, 1948, 3, 501.

6. Thompson, R. H. S., and Watson, D., Serum copper levels in pregnancy and pre-eclampsia. J. Clin. Path., 1949, 2, 193.

7. Heilmeyer, L., Keiderling, W., and Stüwe, G., Kupfer und Eisen als körpereigene Wirkstoffe und ihre Bedeutung beim Krankheitsgeschehen. Fischer, Jena, 1941.

8. Robinson, J. C., A simple method for determining serum copper. J. Biol. Chem., 1949, 179, 1103.

9. Sachs, A., Levine, V. E., Hill, F. C., and Hughes, R., Copper and iron in human blood. Arch. Int. Med., 1943, 71, 489.

10. Sarata, U., Studies in the biochemistry of copper. VI. Copper in relation to the menstruation and pregnancy, with the copper content of men's blood. Japan. J. Med. Sc., II. Biochem., 1935, 3, 1.

11. Holmberg, C. G., Uber die Verteilung des Kupfers zwischen Plasma und Roten Blutkörperchen bei extremen physiologishen Verschiebungen im $\mathrm{Cu}$ Gehalt des Blutes. Acta physiol. Scandinav., 1941, 2, 71.

12. Cartwright, G. E., Copper metabolism in human subjects, in Copper Metabolism: A symposium on animal, plant and soil relationships, edited by W. D. McElroy and B. Glass. Johns Hopkins University Press, Baltimore, 1950, 274.

13. Gubler, C. J., Lahey, M. E., Ashenbrucker, H., Cartwright, G. E., and Wintrobe, M. M., Studies on copper metabolism. I. A method for the determination of copper in whole blood, red blood cells, and plasma. J. Biol. Chem., 1952, 196, 209.

14. Munch-Petersen, S., The variations in serum copper in the course of 24 hours. Scandinav. J. Clin. \& Lab. Invest., 1950, 2, 48.

15. Hamilton, L. D., Gubler, C. J., Cartwright, G. E., and Wintrobe, M. M., Diurnal variation in the plasma 
iron level of man. Proc. Soc. Exper. Biol. \& Med., 1950, 75, 65.

16. Locke, A., Main, E. R., and Rosbash, D. O., The copper and non-hemoglobinous iron contents of the blood serum in disease. J. Clin. Invest., 1932, 11, 527.
17. Sachs, A., Levine, V. E., and Griffith, W. O., Blood copper and iron in relation to menstruation. $J$. Lab. \& Clin. Med., 1938, 23, 566.

18. Leverton, R. M., and Binkley, E. S., The copper metabolism and requirement of young women. $\mathrm{J}$. Nutrition, 1944, 27, 43. 